Belinda Tan. The company conducts virtual clinical trials through a telemedicine platform that allows researchers to easily find participants, who are able to avoid a trip to the clinic and get instructions from study staff through video calls at home. The platform serves as a data repository for all Science 37's trials, and staff members have access to some, depending on their role. Tan says that, for her as a physician, the repository acts like a clinical-trial EHR for participants.

Trial participants use mobile apps on smartphones provided by Science 37 to get their daily task list - for example, to complete a questionnaire or wait for a nurse

嵌 to visit. To make these virtual trials work, Science 37 seeks not only conventional CRO candidates who have experience with clinical data, but also marketing and media specialists, web engineers, product designers, graphic designers and others.

Salaries for CRO employees vary widely depending on the level of education and job responsibilities. Clinical-research associates, who typically do not have $\mathrm{PhDs}$, earn $\$ 50,000-65,000$ on average in the United States, and clinical-research managers and clinical-research directors, who might have a doctorate, can earn more than $\$ 100,000$.

Because they work with multiple clients, CROs tend to offer job stability - if one project fails or ends suddenly, the company can shift flexibly to another project with a different sponsor. And because the work is fast-paced and varied, employees can often broaden their skill sets and climb the career ladder more quickly than they would working at a pharmaceutical company.

Chakrabarti concedes that she misses one element of academic research. "You can follow a drug there from birth to clinic," she says. Conversely, CRO scientists often work with many different drug candidates at varying stages of development. "You have confidentiality agreements with these client companies, so you don't know anything about the compound. You do the assay but you don't know what happens later," she says. "Even when a molecule leaves a powerful impression - like, 'this is the strongest inhibitor I've ever seen' - your interest in a particular project has to stop with a particular deadline. This is what I find sad."

At least once so far, however, a chance run-in has brought the process full circle for her. At a cancer-therapeutics conference in Philadelphia, Pennsylvania, last October, Chakrabarti saw one of her clients presenting data about a familiar compound. She asked him if it was one that she had screened. Indeed, it was, he said, and the compound was heading into clinical trials.

Esther Landhuis is a freelance science journalist in the San Francisco Bay Area, California.

COLUMN

\title{
Convert weaknesses into assets
}

\section{Work out what you really enjoy doing, and pitch your skills accordingly, says Lia Paola Zambetti.}

C T' 'm afraid I won't renew your contract. I am giving you as much advance notice as I can so that you can find something else."

Hearing these words from my supervisor's mouth left me reeling. As a native of Italy, and as a postdoctoral researcher in a nation outside the European Union, I had a visa that depended on my having a work contract. Without a job, I would have to leave the country shortly after the end of my contract.

Furthermore, the words felt like a death knell for my research career. Surely no one would ever hire me for a second postdoc when this one had failed to yield any research papers. What would I do in a few months' time when my postdoc ended? I was literally dizzy - I needed a strategy to find another position, and fast.

That was a tough week, but I am now grateful for that shocking announcement: it gave me clarity and enough time to make a plan.

The deadline made me think hard about my next steps. Somehow, I was able to start spelling out to myself what I emphatically did not want to do any more. It doesn't sound like the most logical step ever - surely, planning what you actually want to do makes more sense but it was spectacularly helpful in clarifying my thoughts. Soon, I came up with a two-pronged strategy: first, look only for a research project that perfectly matches my wishes and skills; second, explore non-academic options as a real possibility - for the first time.

Because it looked increasingly likely that my future career was going to be outside academic research, I set out to turn my weaknesses into strengths. All the points that my supervisors and potential employers had highlighted as faults for a researcher - a poor publication record; no specific research niche; a tendency to 'waste time' reading papers from very different fields; and indulging my passion for writing - I aimed to turn into strengths for non-lab-based jobs.

Because I couldn't count on papers to speak for my research, I decided to network more. I converted my lack of a speciality into a 'broad and diverse background' and an ability to speak knowledgeably to scientists from different fields. My keen interest in writing, seen by some as a time sink, nudged me towards jobs in editing and science writing — something I had

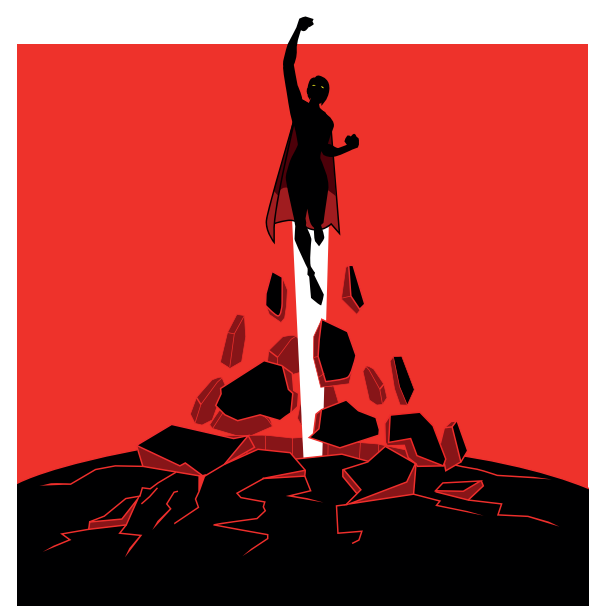

considered only as a vague dream.

I was not sure whether a good occupational fit for me existed, but I still had a few months to find out, so I set up informational chats with nearly everyone I could think of. And, for the first time ever, I was always straightforward about what I was - and was not - looking for in my new role.

One serendipitous talk on a Saturday led to a meeting with the director of the institute where I was doing my postdoc, which in turn led to an informal chat with a senior representative from the institute's marketing and corporate communications unit. She had been tasked with forming a science-communication team on an institution-wide level, and wanted to recruit a scientist.

Three months and two interviews later, the representative became my boss, and I had found my perfect fit in a role that focused on science communication and editing and that was completely away from the bench. As it happened, I also received an offer for a postdoctoral research project that aligned perfectly with my skills and interests. I regretfully felt obliged to decline it.

In the end, although it took all the time I had, I got not one but two great offers. And both matched my skills and interests - all because I had been clear about what I no longer wanted and because I had turned my weaknesses into strengths.

Lia Paola Zambetti is a senior project officer at the University of Sydney's Research Portfolio in Australia. 